Article

\title{
Synthesis, structural analysis and evaluation of the catalytic activity of a non-symmetric $N$-(salicylidene)diethylenetriamine complex of copper(II)
}

\author{
Hassan HOSSEINI-MONFARED ${ }^{\mathrm{a}, *}$, Sohaila ALAVI a, Milosz SICZEK ${ }^{\mathrm{b}}$ \\ a Department of Chemistry, University of Zanjan, 45195-313, Zanjan, Islamic Republic of Iran \\ ${ }^{b}$ Faculty of Chemistry, University of Wroclaw, Joliot-Curie 14, Wroclaw 50-383, Poland
}

A R T I C L E I N F O

Article history:

Received 24 February 2013

Accepted 13 May 2013

Published 20 July 2013

Keywords:

Crystal structure

Copper(II) complex

Non-symmetric Schiff base

Catalyst

Hydrogen peroxide

\begin{abstract}
A B S T R A C T
A new copper(II) complex of a non-symmetric Schiff base, [CuII (saldien) $\left.\left(\mathrm{H}_{2} \mathrm{O}\right)\right]^{+}(\mathbf{1})$, has been synthesized and characterized by elemental analysis and several other spectroscopic methods (Hsaldien $=N$-(salicylidene)diethylenetriamine). The crystal structure of $\mathbf{1}$ has also been determined by X-ray crystallography. The geometry of the complex cation in $\mathbf{1}$ was found to be distorted square pyramidal with the mononegative Schiff base coordinating to the copper in a tetradentate mode via the $O, N, N^{\prime}$, and $N^{\prime \prime}$-donor atoms. The remaining coordination site was occupied by the 0 atom of a $\mathrm{H}_{2} \mathrm{O}$ molecule in the axial position. The catalytic potential of $\mathbf{1}$ was tested in the oxidation reactions of cyclooctene and cyclohexene with aqueous $30 \% \mathrm{H}_{2} \mathrm{O}_{2} / \mathrm{NaHCO}_{3}$ in acetonitrile. These reactions proceeded smoothly to give the corresponding epoxides with selectivity levels greater than $99 \%$. This catalytic system also showed high levels of activity and selectivity towards the oxidation of cyclohexane (i.e., cyclohexanol $37 \%$ and cyclohexanone 54\%) in comparison with most of the other Cu-based systems reported in the literature.
\end{abstract}

(C) 2013, Dalian Institute of Chemical Physics, Chinese Academy of Sciences. Published by Elsevier B.V. All rights reserved.

\section{Introduction}

The catalytic oxidation of hydrocarbons is of particular interest to synthetic chemists, and reactions of this type have been used routinely for some time for the introduction of a variety of different functionalities, including diols, epoxides, alcohols, and carbonyl compounds [1,2]. It is well known that the derivatives of different transition metals can efficiently catalyze the oxygenation of hydrocarbons using molecular oxygen or peroxides, including the inexpensive and environmentally friendly oxidizing agent $\mathrm{H}_{2} \mathrm{O}_{2}$ [3-6]. The development of processes for the selective oxidation of alkanes represents an important industrial problem because of the inert nature of hydrocarbons, which makes the activation of their $\mathrm{C}-\mathrm{H}$ bonds particularly difficult to promote. Reactions of this type are generally conducted under forcing and aggressive conditions, including high temperatures and pressures [7].

Considerable research efforts have been focused on the development of new catalysts for the oxidization of cyclohexane under mild conditions [8]. For the commercial oxidation of cyclohexane by air at $160{ }^{\circ} \mathrm{C}$ with a $\mathrm{Co}(\mathrm{II})$ catalyst [9], the desired products (cyclohexanol and cyclohexanone) typically constitute $85 \%$ of the products in the reaction mixture at a conversion of only $4 \%$. Cyclohexane is an important raw material, and its oxidation products, cyclohexanol and cyclohexanone, are adipic acid precursors. Large quantities of adipic acid are used in industrial manufacture processes, including the production of nylon-6, nylon-66, urethane foams, lubricant

\footnotetext{
*Corresponding author. Tel: +98-241-5152576; Fax: +98-241-5283203; E-mail: monfared@znu.ac.ir 
additives, pharmaceutical intermediates, insecticides and bactericides $[10,11]$. Although several different cyclohexane oxidation reactions catalyzed by metallic complexes have been reported in the literature [12-17], the product yields are usually low [17]. In the majority of these cases, the catalysts used for the oxidation have been based on ligand systems such as ethylenediamine [18], bipyridine [19], salen [20], and phthalocyanine [21] ligands. Schiff base metal complexes are one of the most important stereochemical models in transition metal coordination chemistry because of their facile preparation and structural variability [22,23]. The electronic and structural properties of ligands usually play an important role in determining the properties of the catalyst $[24,25]$. In the symmetric salen Schiff base complexes studied to date, the two identical salicylaldehyde moieties on both sides of the diamine in the ligands make equal electronic and steric contributions. In contrast, unsymmetrical combinations allow for the electronic properties on one side of the diamine and the steric effects on the other side of the diamine to be simultaneously and collectively tuned to maximize the performance of the non-symmetrical Schiff base catalysts. Unsymmetrical Schiff bases can bind with multiple metal centers through a variety of different coordination modes, allowing for the successful synthesis of homo- or heteronuclear metal complexes with interesting stereochemical properties [26-29].

Herein, we report the synthesis and structural elucidation of the copper(II) complex of the non-symmetrical Schiff base ligand $N$-(salicylidene)diethylenetriamine (Hsaldien). Furthermore, the catalytic activity of the complex was evaluated for the oxidation of hydrocarbons with a mixture of $\mathrm{H}_{2} \mathrm{O}_{2}$ and $\mathrm{NaHCO}_{3}$. The reaction conditions were optimized by varying the reaction temperature, molar ratio of the oxidant to the alkene, and the reaction solvent. Following a $5 \mathrm{~h}$ reaction period under the optimized reaction conditions, 91\% of the cyclohexane was converted to a mixture of oxidized products with a selectivity of $59 \%$ for the cyclohexanone. The ligand used in the current study has also been used in the synthesis of metal-organic complexes [30,31]. The oxidation reactions of phenol and hydroquinone catalyzed by the symmetric copper(II) and oxovanadium(IV) complexes of $N, N^{\prime}$-bis(salicylidene)diethylenetriamine covalently bonded to chloromethylated polystyrene have been reported [32].

\section{Experimental}

All of the starting materials used in the current study were purchased from commercial suppliers and used without further purification. Infrared (IR) spectra were recorded on a Bruker FT-IR spectrophotometer as $\mathrm{KBr}$ pellets in the 4000-400 $\mathrm{cm}^{-1}$ region. Ultroviolet-visible (UV-Vis) solution spectra were recorded on a Thermo Spectronic Helios Alpha spectrometer. The products of the oxidation reaction were analyzed using an HP Agilent 6890 gas chromatograph equipped with a HP-5 capillary column (phenyl methyl siloxane, $30 \mathrm{~m} \times 320 \mu \mathrm{m} \times 0.25 \mu \mathrm{m}$ ) and a flame ionization detector.

\subsection{Synthesis of $\mathrm{N}$-(salicylidene)diethylenetriamine (Hsaldien)}

A solution of diethylenetriamine $(0.103 \mathrm{mg}, 0.10 \mathrm{mmol})$ in ethanol was added to a solution of salicylaldehyde $(0.122 \mathrm{mg}$, $0.10 \mathrm{mmol}$ ) in ethanol, and the resulting yellow solution was heated at reflux for $3 \mathrm{~h}$. The reaction solvent was then removed under vacuum to give the desired product as a dark yellow oil (0.187 g, 91\%). IR (KBr, cm-1): 3412 (w, br, O-H), 3062 (w, $\mathrm{NH}), 2928$ (m), 2842 (m), 1632 (vs, C=N), 1279 (s, Ar-OH), 1214 (s).

\subsection{Synthesis of the $\left[\mathrm{Cu}\right.$ (II saldien) $\left.\left(\mathrm{H}_{2} \mathrm{O}\right)\right]\left(\mathrm{NO}_{3}\right)_{0.75}\left(\mathrm{~N}_{3}\right)_{0.25}$ complex (1)}

Schiff base Hsaldien (28.9 mg, $0.14 \mathrm{mmol}$ ), copper(II) nitrate hexahydrate $(41.4 \mathrm{mg}, 0.14 \mathrm{mmol}$ ), and sodium azide (46.8 mg, $0.72 \mathrm{mmol}$ ) were placed in the main arm of a branched tube ('branched tube' method [33]). A 1:1 (v/v) mixture of ethanol and water was then added to the tube to fill the arms. The tube was then sealed and the arm containing the reagents immersed in an oil bath at $60{ }^{\circ} \mathrm{C}$, whereas the other arm was held at ambient temperature. Following a $24 \mathrm{~h}$ period under these conditions, violet crystals of $\mathbf{1}$ that were suitable for X-ray analysis were deposited in the cooler arm in an $80 \%$ yield (38.4 mg). IR (KBr, cm-1): 3422 (m, br, O-H), 3312 (m, $\mathrm{N}-\mathrm{H}$ ), 3193 (m, N-H), 1644 (s, C=N), 1596 (s), 1384 (vs, $\mathrm{NO}_{3}^{-}$). $\mathrm{UV} / \mathrm{Vis}\left(\mathrm{CH}_{3} \mathrm{OH}, c=1.0 \times 10^{-4} \mathrm{~mol} / \mathrm{L}, \lambda_{\max }(\mathrm{nm})\right.$ with $\varepsilon\left(\mathrm{L} \mathrm{mol}^{-1}\right.$ $\mathrm{cm}^{-1}$ )): 228 (25500), 238 (25067), 266 (17640), 363 (5580), 580 (200). Elemental analysis: Calcd. for $\mathrm{C}_{11} \mathrm{H}_{18} \mathrm{CuN}_{4.5} \mathrm{O}_{4.25}$ (344.83); C 38.31\%, H 5.26\%, N 18.28\%, Cu 18.43\%. Found C $38.29 \%$, H 5.28\%, N $18.20 \%$, Cu $19.00 \%$.

\subsection{X-ray crystallography}

X-ray quality crystals of 1 were obtained from a 1:1 (v/v) mixture of ethanol and water. A violet-colored crystal of $\mathbf{1}$ was measured at 100(2) $K_{\alpha}$ on an Oxford XCalibur diffractometer with monochromated Mo $K_{\alpha}$ radiation $(\lambda=0.71073 \AA)$. The structure was solved by direct methods with SHELXS [34] and refined with full-matrix least-squares techniques on $F^{2}$ with SHELXL [34]. The crystal data and refinement parameters are shown in Table 1.

CCDC 923723 contains the supplementary crystallographic data for 1 . These data can be obtained free of charge from The Cambridge Crystallographic Data Centre via www.ccdc.cam.ac. uk/data_request/cif.

\subsection{General procedure for the oxidation of hydrocarbons}

The liquid phase catalytic oxidations were carried out under air (atmospheric pressure) in a $25 \mathrm{ml}$ round bottom flask equipped with a magnetic stirrer and immersed in a thermostated oil bath. In a typical experiment, $30 \% \mathrm{H}_{2} \mathrm{O}_{2}(3.0 \mathrm{mmol})$ was added to a flask containing the catalyst $(0.001 \mathrm{~g})$ and a representative hydrocarbon ( $1 \mathrm{mmol})$ in a solvent $(3 \mathrm{ml})$ with $n$-octane $(0.1 \mathrm{~g})$, which was used as an internal standard, and $\mathrm{NaHCO}_{3}$ (1 mmol), which was used as a co-catalyst. The progress of the reaction was monitored using a gas chromatograph equipped with a capillary column and a flame ionization detec- 
Table 1

Crystal data for $\left[\mathrm{Cu}^{\mathrm{II}}\right.$ (saldien) $\left.\left(\mathrm{H}_{2} \mathrm{O}\right)\right]\left(\mathrm{NO}_{3}\right)_{0.75}\left(\mathrm{~N}_{3}\right)_{0.25}(\mathbf{1})$.

\begin{tabular}{lc}
\hline Net formula & $\mathrm{C}_{11} \mathrm{H}_{18} \mathrm{CuN}_{3} \mathrm{O}_{2}, 0.746\left(\mathrm{NO}_{3}\right), 0.254\left(\mathrm{~N}_{3}\right)$ \\
Size & $0.4 \mathrm{~mm} \times 0.25 \mathrm{~mm} \times 0.25 \mathrm{~mm}$ \\
Chemical formula sum & $\mathrm{C}_{11} \mathrm{H}_{18} \mathrm{CuN}_{4.51} \mathrm{O}_{4.24}$ \\
$M_{\mathrm{r}}\left(\mathrm{g} \mathrm{mol}^{-1}\right)$ & 344.74 \\
Crystal system & Monoclinic \\
Space group & $P 21 / \mathrm{c}$ \\
$a(\AA)$ & $9.077(3)$ \\
$c(\AA)$ & $14.538(4)$ \\
$b(\AA)$ & $10.768(3)$ \\
$\beta\left({ }^{\circ}\right)$ & $101.53(3)$ \\
$V\left(\AA^{3}\right)$ & $1392.3(7)$ \\
$Z$ & 4 \\
$T_{\text {min, }} T_{\text {max }}$ & $0.723,0.781$ \\
Reflections measured & 7927 \\
$\mu\left(\right.$ mm $\left.^{-1}\right)$ & 1.593 \\
Reflections in refinement & 4656 \\
Parameters & 203 \\
Restraints & 0 \\
$R\left(F_{\text {obs }}\right)$ & 0.0283 \\
$R$ w $\left(F_{2}\right)$ & 0.0657 \\
$S$ & 1.008 \\
\hline
\end{tabular}

tor. The reaction products were quantified by gas chromatography and identified through a comparison of their retention times and spectral data with those of the authentic samples. No degradation of the ligand was observed during the reaction process and the violet color of the solution remained the same following the $5 \mathrm{~h}$ reaction period.

Control reactions were carried out under the same conditions in the absence of the catalyst and $\mathrm{H}_{2} \mathrm{O}_{2}$. None of the desired products were formed during these control reactions.

The complex was found to be stable under the oxidation conditions over the $5 \mathrm{~h}$ reaction period. Although the blue-violet color of the catalyst solution became a little faint following the $5 \mathrm{~h}$ reaction period, its UV-Vis spectrum was comparable with that of the fresh complex.

\section{Results and discussion}

\subsection{Synthesis and spectroscopic analysis of \\ $\left[\mathrm{Cu}^{\text {II }}\right.$ (saldien) $\left.\left(\mathrm{H}_{2} \mathrm{O}\right)\right]\left(\mathrm{NO}_{3}\right)_{0.75}\left(\mathrm{~N}_{3}\right)_{0.25}$}

The non-symmetric Schiff base ligand was synthesized in high yield and purity via the monocondensation of salicylaldehyde and diethylenetriamine in ethanol. The copper complex with the Hsaldien ligand was prepared by treating an ethanol/water solution of the ligand with $\mathrm{Cu}\left(\mathrm{NO}_{3}\right)_{2} \cdot 6 \mathrm{H}_{2} \mathrm{O}$ and $\mathrm{NaN}_{3}$ in a molar ratio of $1: 1: 5$, respectively (Scheme 1 ). It was envisaged that the use of sodium azide would lead to the formation of a coordination polymer, but this strategy led instead to the formation of a mononuclear copper(II) complex.

The IR spectrum of the free Hsaldien ligand showed stretching bands at 1279, 1632, and $3062 \mathrm{~cm}^{-1}$, which were attributed to the phenolic $\mathrm{C}-\mathrm{OH}, \mathrm{C}=\mathrm{N}$, and $\mathrm{N}-\mathrm{H}$ bonds, respectively [35]. The band at $3412 \mathrm{~cm}^{-1}$ was assigned to $v(\mathrm{O}-\mathrm{H})$ vibrations associated with intramolecular hydrogen bonding interactions, whereas the band at $1214 \mathrm{~cm}^{-1}$ was attributed to the phenolic $\delta(\mathrm{O}-\mathrm{H})$ bond [36]. The weak band corresponding

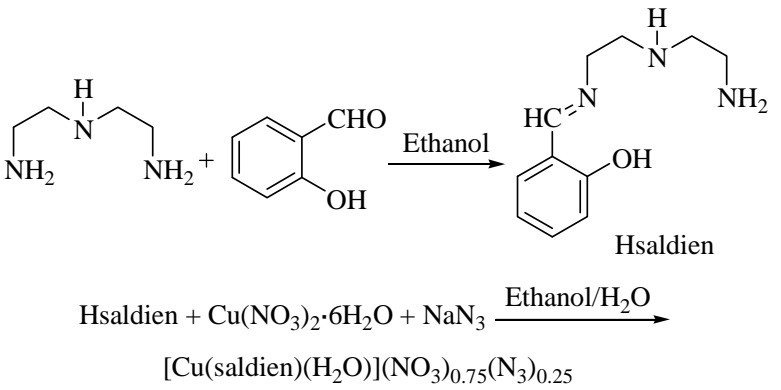

Scheme 1. Syntheses of the non-symmetric Schiff base (Hsaldien) and complex $\left[\mathrm{Cu}\right.$ (II (saldien) $\left.\left(\mathrm{H}_{2} \mathrm{O}\right)\right]\left(\mathrm{NO}_{3}\right)_{0.75}\left(\mathrm{~N}_{3}\right)_{0.25}$.

to the $v(\mathrm{O}-\mathrm{H})$ vibrations of the Hsaldien ligand at $3412 \mathrm{~cm}^{-1}$ indicated the presence of an intramolecular hydrogen bonding interaction $(\mathrm{O}-\mathrm{H} \cdots \mathrm{N})$ in the ligand [35]. For complex 1, the absence the of $\delta(\mathrm{O}-\mathrm{H})$ (phenolic) band, together with shifts in azomethine $\left(\mathrm{C}=\mathrm{N}, 12 \mathrm{~cm}^{-1}\right)$ and $\mathrm{N}-\mathrm{H}$ bands compared with the free Hsaldien ligand, indicated the coordination of (saldien)through the phenolate oxygen, azomethine nitrogen, and amine oxygen atoms in the complex $\mathbf{1}$. The IR spectrum of $\mathbf{1}$ also contained an intense absorption at $1384 \mathrm{~cm}^{-1}$, which was attributed to the presence of a nitrate counter ion. This result provided further confirmation that $\mathbf{1}$ existed as an ionic complex.

Following the complexation process, the UV-Vis spectrum in methanol contained absorbance bands at $\lambda_{\max }\left(\varepsilon, \mathrm{L} \mathrm{mol}^{-1} \mathrm{~cm}^{-1}\right)$ = 228 (25500), 238 (25067), 266 (17640), 363 (5580), and 580 nm (200) (Fig. 1). The complex gave a UV-Vis spectrum similar to that of the ligand. Based on their extinction coefficients, these bands were assigned to intra ligand $\pi \rightarrow \pi^{*}(228,238,266$ $\mathrm{nm}$ ) and $n \rightarrow \pi^{*}$ (363 $\mathrm{nm}$ ) transitions. The higher energy band at $363 \mathrm{~nm}$ with a high extinction coefficient value was attributed in part to charge transfer (LMCT) transitions between the coordinated phenolate- $\mathrm{O}$ and the $\mathrm{Cu}(\mathrm{II})$. Furthermore, complex 1 exhibited a ligand field $d-d$ transition at $580 \mathrm{~nm}$ (200 L mol-1 $\mathrm{cm}^{-1}$ ) (Fig. 1, inset).

\subsection{Crystal structure}

The molecular structure of the catalyst with numbering is

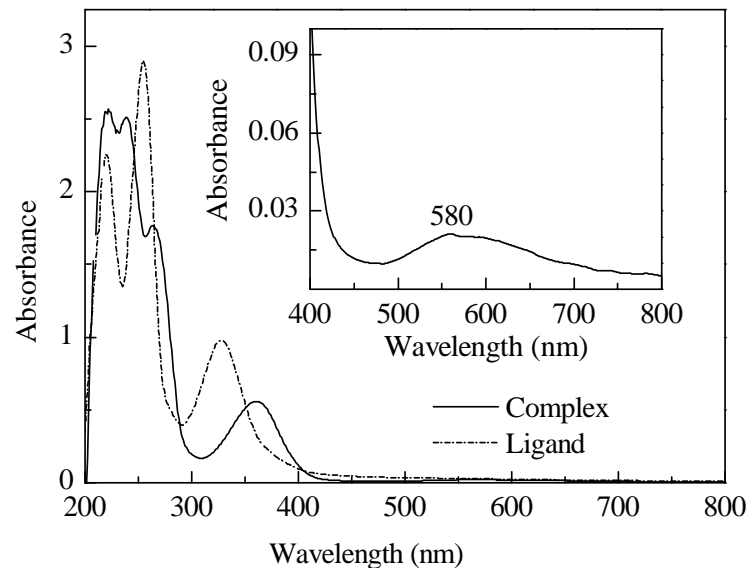

Fig. 1. The UV-Vis spectra of the $\left[\mathrm{Cu}\right.$ II (saldien) $\left.\left(\mathrm{H}_{2} \mathrm{O}\right)\right]\left(\mathrm{NO}_{3}\right)_{0.75}\left(\mathrm{~N}_{3}\right)_{0.25}$ complex and the Hsaldien ligand $(c=0.1 \mathrm{mmol} / \mathrm{L})$ recorded in methanol. The inset shows the $d$ - $d$ transition in the $\mathrm{Cu}(\mathrm{II})$. 


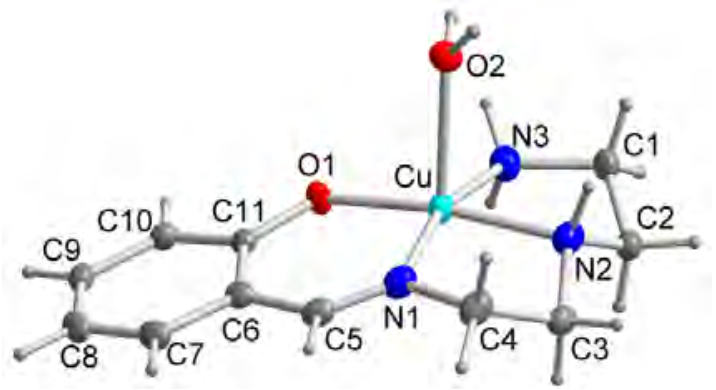

Fig. 2. The coordination environment of 1 (probability 50\%). Selected interatomic bond distances $(\AA)$ and angles $\left({ }^{\circ}\right)$ : $\mathrm{Cu}-01,1.925(1)$; $\mathrm{Cu}-\mathrm{N} 1$, 1.946(1); $\mathrm{Cu}-\mathrm{N} 2, \quad 2.007(1) ; \mathrm{Cu}-\mathrm{N} 3, \quad 2.014(1) ; \mathrm{Cu}-02, \quad 2.317(1)$; 01-Cu-N1，93.16(6); 01-Cu-N2，171.58(5); 01-Cu-N3，94.82(6); 01-Cu-02, 95.78(4); N1-Cu-N2, 84.75(6); N1-Cu-N3, 163.91(5).

depicted in Fig. 2. The compound consisted of a $\left[\mathrm{Cu}^{\mathrm{II}} \text { (saldien) }\left(\mathrm{H}_{2} \mathrm{O}\right)\right]^{+}$cation, as well as nitrate and azide anions, which were located in the structural voids of the crystal and disordered over two positions with occupancies of $0.254 \mathrm{~N}_{3}{ }^{-}$ and $0.746 \mathrm{NO}_{3}{ }^{-}$. The geometry of the $\mathrm{Cu}(\mathrm{II})$ atom in the cation was distorted square pyramidal ( $\tau=0.13$ according to $\tau=$ (difference between the two largest angles)/60 for five coordinated metal centers allows for the distinction between trigonal-bipyramidal (ideally $\tau=1$ ) and square-pyramidal (ideally $\tau$ $=0$ ) [37]), with the copper coordinated to three nitrogen atoms and one oxygen atom from the non-symmetric ligand and one oxygen atom from a coordinated water molecule. The four coordination atoms from the ligand constituted the basal plane, whereas the oxygen atom from the $\mathrm{H}_{2} \mathrm{O}$ molecule occupied the axial position. The $\mathrm{Cu}(\mathrm{II})$ atom was located $0.186 \AA$ above the plane in the direction of the water molecule. Although the bond lengths of the three $\mathrm{Cu}-\mathrm{N}$ bonds, including the $\mathrm{Cu}(\mathrm{II})$ contacts with the primary amine, secondary amine and imine, were different from one another, they were in normal bond length range. The dihedral angle between the equatorial plane $(01$, $\mathrm{N} 1, \mathrm{~N} 2, \mathrm{~N} 3$ ) and the aromatic ring was nearly parallel $\left(3.08(4)^{\circ}\right)$. The crystal structure was stabilized by intermolecular hydrogen bonding interactions, which formed a two-dimensional network parallel to the (100) plane (Figure not shown). The complex cations were connected with each other through the $\mathrm{O} 2-\mathrm{H} \cdots \mathrm{O} 1$ and $\mathrm{N} 3-\mathrm{H} \cdots \mathrm{O} 2$ interactions to a form dimer.

\subsection{Catalytic activity}

Classical stoichiometric oxidants, such as dichromate and permanganate, should be replaced with new environmentally friendly catalytic processes that use clean oxidants such as molecular $\mathrm{O}_{2}$ and $\mathrm{H}_{2} \mathrm{O}_{2}$ [5,38]. The catalytic oxidation of cyclooctene with $\mathrm{H}_{2} \mathrm{O}_{2}$ was studied in the presence of $\mathbf{1}$. All of the reactions were carried out with $1 \mathrm{mmol}$ of cyclooctene in $\mathrm{CH}_{3} \mathrm{CN}$ at $80^{\circ} \mathrm{C}$ in the presence of catalyst. Cyclooctene oxide was formed as the sole product of these reactions. The results of control experiments revealed that the presence of the catalyst and the oxidant were essential to the oxidation process. The oxidation of cyclooctene in the absence of $\mathrm{H}_{2} \mathrm{O}_{2}$ did not occur, whereas in the absence of a catalyst the oxidation only

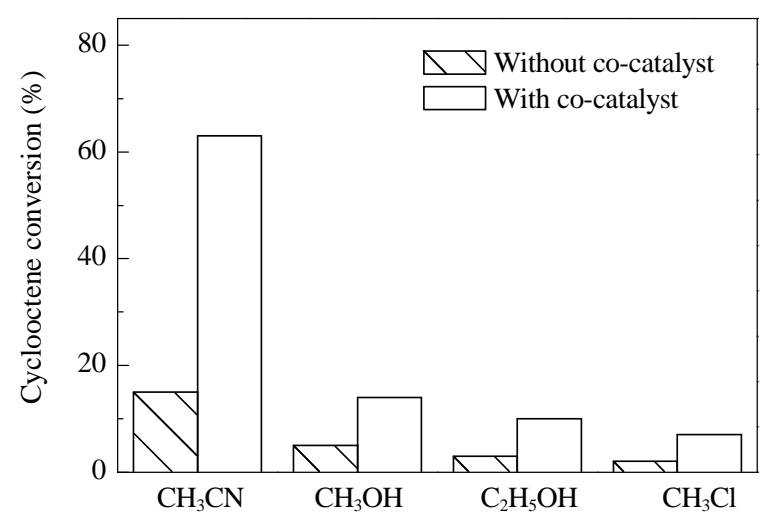

Fig. 3. The effect of $\mathrm{NaHCO}_{3}$ as a co-catalyst towards the oxidation of cyclooctene by $1 / \mathrm{H}_{2} \mathrm{O}_{2}$ in different solvents.

proceeded by up to $5 \%$ after $24 \mathrm{~h}$. The addition of a co-catalyst $\left(\mathrm{NaHCO}_{3}\right)$ increased the cyclooctene conversion by $1 / \mathrm{H}_{2} \mathrm{O}_{2}$ from $15 \%$ to $63 \%$ after $5 \mathrm{~h}$ (Fig. 3). To further optimize the process to achieve the maximum oxidation of cyclooctene, the effect of different solvents was studied (Fig. 3). The order of the catalyst activity in the absence or presence of $\mathrm{NaHCO}_{3}$ was the same. The highest conversion was obtained in acetonitrile ( $63 \%$ after $5 \mathrm{~h})$. The activity of the catalyst in the different solvents tested followed the order acetonitrile $>$ methanol $>$ ethanol $>$ chloroform. This order reflected the relative dielectric constants $\left(\varepsilon / \varepsilon_{0}\right)$ of the solvents, which were $37.5,32.7,24.3$, and 4.9 , respectively [39]. These data suggested that the higher level of conversion observed in acetonitrile was related to its high dielectric constant.

To establish the scope for the activity of $\left[\mathrm{Cu}\right.$ II (saldien) $\left.\left(\mathrm{H}_{2} \mathrm{O}\right)\right]\left(\mathrm{NO}_{3}\right)_{0.75}\left(\mathrm{~N}_{3}\right)_{0.25}$, the oxidation reactions of cyclohexene, cyclohexane, and ethylbenzene were also examined under the optimized conditions (i.e., a 3:1 (mol/mol) mixture of $\mathrm{H}_{2} \mathrm{O}_{2}$ and cyclooctene in acetonitrile at $80{ }^{\circ} \mathrm{C}$ with a co-catalyst), and the results are shown in Table 2 . The oxidation of cyclohexene by complex $\mathbf{1}$ was particularly impressive and showed excellent selectivity towards cyclohexene oxide. Complex 1 exhibited a high level of selective in comparison with most of the other systems reported in the literature for the same transformation [40]. Cyclohexene possesses two allylic positions, in addition to double bond functional group, that are activated towards oxidation and therefore very easily oxidized [6,41-43]. Unfortunately, the catalyst was found to be inactive towards the oxidation of ethylbenzene.

The oxidation of cyclohexane under mild conditions is a topic of considerable interest [44]. Using our newly developed catalyst 1 in the presence of $\mathrm{H}_{2} \mathrm{O}_{2}$ and $\mathrm{NaHCO}_{3}$, cyclohexane was successfully oxidized to a mixture of cyclohexanol and cyclohexanone $(1.4: 1, \mathrm{~mol} / \mathrm{mol})$ in a combined yield of $91 \%$ (Table 2, entry 3). This particular result was similar to those reported in the literature involving the use of dinuclear Mn(IV) $[45,46]$. Shul'pin et al. $[45,46]$ reported the oxidation of cyclohexane using the binuclear manganese(IV) complex $\left(\left[\mathrm{LMn}^{\mathrm{IV}}(\mathrm{O})_{3} \mathrm{Mn}^{\mathrm{IV}} \mathrm{L}\right]^{2+}\right.$, L: 1,4,7-trimethyl-1,4,7-triazacyclononane) as a catalyst. This catalyst gave a mixture of cyclohexanol and cyclohexanone $(1.38: 1, \mathrm{~mol} / \mathrm{mol})$ with a conversion of 
Table 2

Oxidation of different substrates with $\left[\mathrm{Cu}^{\mathrm{II}}(\right.$ saldien $\left.)\left(\mathrm{H}_{2} \mathrm{O}\right)\right]\left(\mathrm{NO}_{3}\right)_{0.75-}$ $\left(\mathrm{N}_{3}\right)_{0.25}$ (1) using $\mathrm{H}_{2} \mathrm{O}_{2} / \mathrm{NaHCO}_{3}$ in acetonitrile.

Entry Substrate

Reaction conditions: Catalyst [Cu mol, substrate $1 \mathrm{mmol}, n$-octane $0.1 \mathrm{~g}$, acetonitrile $3 \mathrm{ml}, \mathrm{H}_{2} \mathrm{O}_{2} 3 \mathrm{mmol}$, $\mathrm{NaHCO}_{3} 1 \mathrm{mmol}, 80^{\circ} \mathrm{C}, 5 \mathrm{~h}$.

a Based on substrate.

$\mathrm{b}$ Turnover number $(\mathrm{TON})=$ mmol of oxidized products per mmol of metal in the catalyst.

$30 \%$. It is noteworthy that this oxidation reaction was conducted in the presence of acetic acid to prevent the decomposition of $\mathrm{H}_{2} \mathrm{O}_{2}$ to $\mathrm{H}_{2} \mathrm{O}$ and oxygen.

Complex 1 was also used to evaluate the oxidation of ethylbenzene. The oxidation proceeded selectively to give acetophenone, but the conversion was low (5\%).

A variety of different homogeneous and heterogeneous $\mathrm{Cu}$-catalysts have been used for the oxidation of cyclohexane with $\mathrm{H}_{2} \mathrm{O}_{2}$ and $t$-BuOOH. None of these catalysts, however, have shown activity and selectivity levels greater than those exhibited by $\left[\mathrm{Cu}^{\mathrm{II}}(\right.$ saldien $\left.)\left(\mathrm{H}_{2} \mathrm{O}\right)\right]\left(\mathrm{NO}_{3}\right)_{0.75}\left(\mathrm{~N}_{3}\right)_{0.25}$. Fernandes et al. [47] reported the use of $[\mathrm{Cu}(\mathrm{OTf})(\mathrm{L})](\mathrm{OTf}),\left[\mathrm{Cu}(\mathrm{L})\left(\mathrm{H}_{2} \mathrm{O}\right)\right](\mathrm{OTf})_{2}$, [Cu(OTf)(LMe)](OTf), [Cu(Lpy)](OTf $)_{2}, \quad\left[\mathrm{Fe}(\mathrm{OTf})_{2}(\mathrm{LMe})\right]$, and [Fe(OTf)(Lpy)](OTf) complexes in the presence of several different $\mathrm{N}$-based additives for the oxidation of cyclohexane. These systems successfully catalyzed the oxidation of cyclohexane to cyclohexanol and cyclohexanone in acetonitrile with $\mathrm{H}_{2} \mathrm{O}_{2}$, with the products being formed in yields of up to $29 \%$ after $6 \mathrm{~h}$ (OTf = trifluoromethanesulfonate, $\mathrm{L}=$ bis- and tris-pyridyl amino and imino thioether ligands). Silva et al. [16] investigated the catalytic oxidation of cyclohexane using the $\mathrm{Cu}(\mathrm{II})$ complexes $\left[\mathrm{Cu}(\mathrm{BMPA}) \mathrm{Cl}_{2}\right]$ and $\left\{\left[\mathrm{Cu}\left(\mathrm{BMPA}^{2} \mathrm{Cl}_{2}\right]-\right.\right.$ $\left.\left[\mathrm{Cu}(\mathrm{BMPA})\left(\mathrm{H}_{2} \mathrm{O}\right) \mathrm{Cl}\right][\mathrm{Cu}(\mathrm{BMPA}) \mathrm{Cl}]\left[\mathrm{CuCl}_{4}\right]\right\}$ with $\mathrm{H}_{2} \mathrm{O}_{2}$ or tert-butyl hydroperoxide in acetonitrile $(\mathrm{BMPA}=$ bis-(2-pyridylmethyl)amine)). The latter of these two catalysts gave the best results, providing the products in a combined yield of $69 \%$ after $24 \mathrm{~h}$. Canhota et al. [17] succeeded in promoting the oxidation of cyclohexane with a series of different 2,2'-bipyridine $\mathrm{Cu}(\mathrm{II})$ complexes. In this particular case, the $\left[\mathrm{Cu} \text { (bipy) }{ }_{3}\right]_{\mathrm{Cl}_{2}},\left[\mathrm{Cu}\left(\right.\right.$ bipy $\left.{ }_{2} \mathrm{Cl}\right] \mathrm{Cl}$, and $\left[\mathrm{Cu}(\right.$ bipy $\left.) \mathrm{Cl}_{2}\right]$ complexes provided the oxidized products in yields of up to $44 \%$ using $\mathrm{H}_{2} \mathrm{O}_{2}$ at $50{ }^{\circ} \mathrm{C}$.

To determine whether the reaction proceeded according

$$
\begin{aligned}
\mathrm{Cu}^{2+}+\mathrm{H}_{2} \mathrm{O}_{2} & \rightarrow \mathrm{Cu}^{+}+\mathrm{H}^{+}+\mathrm{HO}_{2} \\
\mathrm{Cu}^{+}+\mathrm{H}_{2} \mathrm{O}_{2} & \rightarrow \mathrm{Cu}^{2+}+\mathrm{HO}^{-}+\mathrm{HO}^{\bullet} \\
\mathrm{CyH}+\mathrm{HO}^{\bullet} & \rightarrow \mathrm{Cy}+\mathrm{H}_{2} \mathrm{O} \\
\mathrm{Cy}+\mathrm{HO}_{2} & \rightarrow \mathrm{CyOOH} \\
\mathrm{CyOOH} & \rightarrow \mathrm{Cy}-\mathrm{one}+\mathrm{HO}^{\bullet} \\
\mathrm{Cy}^{\bullet}+\mathrm{HO} \bullet & \rightarrow \text { Cy-ol }
\end{aligned}
$$

Scheme 2. A possible mechanism of the oxidation of cyclohexane by $1 / \mathrm{H}_{2} \mathrm{O}_{2} / \mathrm{NaHCO}_{3} / \mathrm{CH}_{3} \mathrm{CN}$.

to a radical-based mechanism, an experiment was conducted involving the addition of the radical inhibitor tert-butanol to the reaction mixture. In this particular case, the desired product was not formed. Furthermore, the oxidation of cyclohexane using the $1 / \mathrm{H}_{2} \mathrm{O}_{2} / \mathrm{NaHCO}_{3} / \mathrm{CH}_{3} \mathrm{CN}$ system did not occur when the reaction was conducted under a nitrogen atmosphere instead of an oxygen atmosphere. Taken together, these results effectively confirmed that free diffusing radicals were present as intermediates in the reaction mixture. The number of free diffusing radicals in a mixture can be enhanced significantly by free radical chains in the presence of $\mathrm{O}_{2}$. Similar results have also been reported in the literature [48]. Based on these results, we have proposed a possible mechanism for the oxidation reaction involving the generation of radical species (Scheme 2) [49]. The increase in the reaction rate observed following the addition of $\mathrm{NaHCO}_{3}$ has been attributed to an increase in the equilibrium concentration of $\mathrm{HOO}^{-}$.

\section{Conclusions}

A new copper(II) complex, [CuII (saldien) $\left.\left(\mathrm{H}_{2} \mathrm{O}\right)\right]\left(\mathrm{NO}_{3}\right)_{0.75-}$ $\left(\mathrm{N}_{3}\right)_{0.25}$ (1), of the non-symmetric Schiff base Hsaldien was synthesized and characterized by spectroscopic methods. The structure of the complex was established by X-ray crystallographic analysis. The catalytic activity of $\mathbf{1}$ was evaluated for the oxidation of a variety of different hydrocarbons using $\mathrm{H}_{2} \mathrm{O}_{2}$ as the terminal oxidant. High levels of selectivity and conversion were obtained in the oxidation reactions of cycloalkenes and cyclohexane.

\section{Acknowledgments}

The authors would like to thank Professor T. Lis for data collection and preliminary structure solving.

We are grateful to the University of Zanjan for providing financial support for this study.

\section{References}

[1] Sheldon R A, Kochi J K. Metal-Catalyzed Oxidations of Organic Compounds. New York: Academic Press, 1981

[2] Punniyamurthy T, Velusamy S, Iqbal J. Chem Rev, 2005, 105: 2329

[3] Mandelli D, do Amaral A C N, Kozlov Y N, Shul'pina L S, Bonon A J, Carvalho W A, Shul'pin G B. Catal Lett, 2009, 132: 235

[4] Strukul G. Catalytic Oxidations with Hydrogen Peroxide as Oxidant. Dordrecht: Kluwer, 1992

[5] Hosseini-Monfared H, Amouei Z.J Mol Catal A, 2004, 217: 161

[6] Ghorbanloo M, Hosseini-Monfared H, Janiak C. J Mol Catal A, 2011, 345: 12 


\section{Graphical Abstract}

Chin. J. Catal., 2013, 34: 1456-1461 doi: 10.1016/S1872-2067(12)60616-0

\section{Synthesis, structural analysis and evaluation of the catalytic activity of a non-symmetric $N$-(salicylidene)diethylenetriamine complex of copper(II)}

Hassan HOSSEINI-MONFARED*, Sohaila ALAVI, Milosz SICZEK

University of Zanjan, Iran; University of Wroclaw, Poland
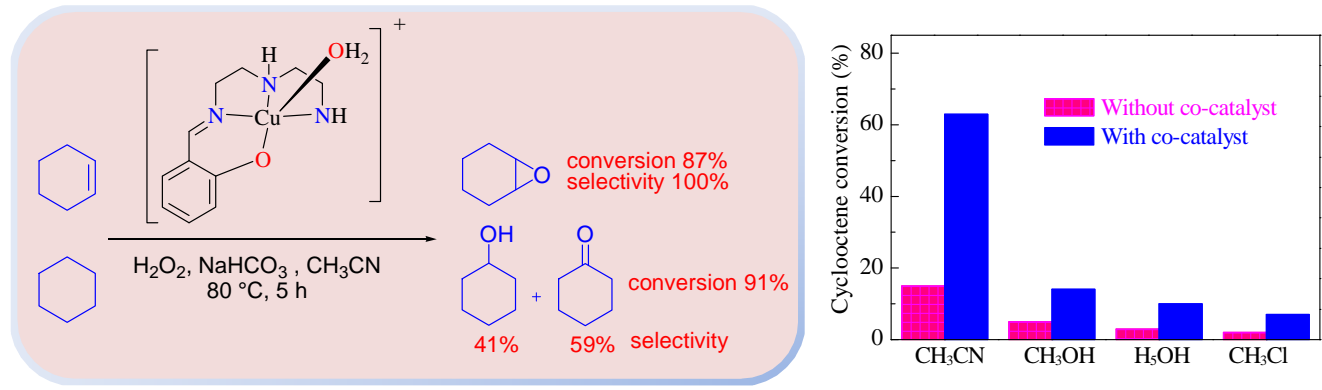

Synthesis and crystal structural analysis of a new copper(II) complex of a non-symmetric Schiff base have been reported. The complex showed high levels of catalytic activity and selectivity towards the oxidation of cycloalkenes and cyclohexane by $\mathrm{H}_{2} \mathrm{O}_{2}$ and $\mathrm{NaHCO}_{3}$.

[7] Crabtree R H. Chem Rev, 1995, 95: 987

[8] Schuchardt U, Cardoso D, Sercheli R, Pereira R, da Cruz R S, Guerreiro M C, Mandelli D, Spinacé E V, Pires E L. Appl Catal A, 2001, 211: 1

[9] Ingold K U. Aldrichim Acta, 1989, 22(3): 69

[10] Yuan Y, Ji H B, Chen Y X, Han Y, Song X F, She Y B, Zhong R G. Org Process Res Dev, 2004, 8: 418

[11] Schuchardt U, Carvalho W A, Spinace E V. Synlett, 1993, 10: 713

[12] Okuno T, Ohba S, Nishida Y. Polyhedron, 1997, 16: 3765

[13] Malachowski M R, Dorsey B T, Parker M J, Adams M E, Kelly R S. Polyhedron, 1998, 17: 1289

[14] Obias H V, Lin Y, Murthy N N, Pidcock E, Solomon E I, Ralle M, Blackburn N J, Neuhold Y M, Zuberbühler A D, Karlin K D. J Am Chem Soc, 1998, 120: 12960

[15] Carvalho N M F, Horn A Jr, Antunes O A C. Appl Catal A, 2006, 305 : 140

[16] Silva A C, Fernández T L, Carvalho N M F, Herbst M H, Bordinhão J, Horn A Jr, Wardell J L, Oestreicher E G, Antunes O A C. Appl Catal A, 2007, 317: 154

[17] Canhota F P, Salomão G C, Carvalho N M F, Antunes O A C. Catal Commun, 2007, 9: 182

[18] Rashmi J, Limye S N. Oxid Commun, 1998, 21: 337

[19] Knops-Gerrits P P, De Vos D, Thibault-Starzyk F, Jacobs P A. Nature, 1994, 369: 543

[20] Bowers C, Dutta P K. J Catal, 1990, 122: 271

[21] Herron N.J Coord Chem, 1988, 19: 25

[22] Yang D S. Acta Crystallogr Sect E, 2005, 61: m249

[23] Butcher R J, Mockler G M, McKern O. Acta Crystallogr Sect E, 2003, 59: $\mathrm{m} 1104$

[24] Jacobsen E N, Zhang W, Güler M L. J Am Chem Soc, 1991, 113: 6703

[25] Jacobsen E N. In: Abel E W, Stone F G A, Wilkinson G, Hegedus L S eds. Comprehensive Organometallic Chemistry II. New York: Pregamon Press, 1995. Vol. 12, 1097

[26] Zanello P, Tamburini S, Vigato P A, Mazzocchin G A. Coord Chem Rev, 1987, 77: 165

[27] Timken M D, Marritt W A, Hendrickson D N, Gagne R A, Sinn E. Inorg Chem, 1985, 24: 4202
[28] Aono T, Wade H, Aratake Y, Matsumoto N, Okawa H, Yoshihisa M. J Chem Soc, Dalton Trans, 1996: 25

[29] Ikawa Y, Nagata T, Maruyama K. Chem Lett, 1993: 1049

[30] Zhu H L, Tong Y X, Chen X M. J Chem Soc, Dalton Trans, 2000: 4182

[31] Zhu H L, Li S Y, He W M, Yu K B. Z Kristallogr, 2002, 217: 599

[32] Maurya M R, Sikarwar S. J Mol Catal A, 2007, 263: 175

[33] Hosseini-Monfared H, Vahedpour M, Mahdavi-Yeganeh M, Ghorbanloo M, Mayer P, Janiak C. Dalton Trans, 2011, 40: 1286

[34] Sheldrick G M. Acta Crystallogr Sect A, 2008, 64: 112

[35] Silverstein R M, Webster F X. Spectroscopic Identification of Organic Compounds. 6th Ed. New York: Wiley, 1998. 101

[36] Adams H, Fenton D E, Minardi G, Mura E, Pistuddi A M, Solinas C. Inorg Chem Commun, 2000, 3: 24

[37] Addison A W, Rao T N, Reedijk J, van Rijn J, Verschoor G C. J Chem Soc, Dalton Trans, 1984: 1349

[38] Arends I W C E, Sheldon R A. Top Catal, 2002, 19: 133

[39] Marcus Y. In: Rydberg J, Musikas C, Choppin G R eds. Principles and Practices of Solvent Extraction. New York: Marcel Dekker, 1992. 23

[40] Appleton A J, Evans S, Lindsay Smith J R. J Chem Soc, Perkin Trans 2, 1996: 281

[41] Hosseini-Monfared H, Abbasi V, Rezaei A, Ghorbanloo M, Aghaei A. Transition Met Chem, 2012, 37: 85

[42] Hosseini-Monfared H, Alavi S, Farrokhi A, Vahedpour M, Mayer P. Polyhedron, 2011, 30: 1842

[43] Hosseini-Monfared H, Kheirabadi S, Asghari Lalami N, Mayer P. Polyhedron, 2011, 30: 1375

[44] Carvalho N M F, Horn A Jr, Antunes O A C. Appl Catal A, 2006, 305: 140

[45] Shul'pin G B, Süss-Fink G, Lindsay Smith J R. Tetrahedron, 1999, 55: 5345

[46] Lindsay Smith J R, Shul'pin G B. Tetrahedron Lett, 1998, 39: 4909

[47] Fernandes R R, Lasri J, da Silva M F C G, da Silva J A L, da Silva J J R F, Pombeiro A J L.J Mol Catal A, 2011, 351: 100

[48] Hosseini-Monfared H, Pousaneh E, Sadighian S, Ng S W, Tiekink E R T. Z Anorg Allg Chem, 2013, 639: 435

[49] Dua Y, Xiong Y L, Li J, Yang X G.J Mol Catal A, 2009, 298: 12 